\title{
Ground Deformation during Papandayan Volcano 2002 Eruption as Detected by GPS Surveys
}

\author{
Hasanuddin Z. Abidin ${ }^{1}$, H. Andreas ${ }^{1}$, M. Gamal ${ }^{1}$, Ony K. Suganda ${ }^{2}$, \\ Irwan Meilano $^{3}$, M. Hendrasto ${ }^{2}$, M. A. Kusuma ${ }^{1}$, D. Darmawan ${ }^{3}$, \\ M. A. Purbawinata ${ }^{2}$, A. D. Wirakusumah ${ }^{2}$ \& F. Kimata ${ }^{3}$ \\ ${ }^{1}$ Department of Geodetic Engineering, Institut Teknologi Bandung (ITB) \\ Jl. Ganesha 10, Bandung 40132, INDONESIA, E-mail: hzabidin@gd.itb.ac.id \\ ${ }^{2}$ Directorate of Volcanology and Geological Hazard Mitigation (DVGHM), \\ J1. Diponegoro 57, Bandung 40132, INDONESIA \\ ${ }^{3}$ Research Center for Seismology and Volcanology (RCSV), \\ Nagoya University, Nagoya, JAPAN
}

\begin{abstract}
Papandayan is an A-type active volcano located in the southern part of Garut Regency, about $70 \mathrm{~km}$ southeast of Bandung, Indonesia. Its earliest recorded eruption, and most violent and devastating outburst occurred in 1772 and the latest eruptions occurred in the period of 11 November to 8 December 2002 , and consisted of freatic, freatomagmatic and magmatic types of eruption.

During the latest eruption period, GPS surveys were conducted at several points inside and around the crater in a radial mode using the reference point located at Papandayan observatory around $10 \mathrm{~km}$ from the crater. At the points closest to the erupting craters, GPS displacements up to a few dm were detected, whereas at the points outside the crater, the displacements were in the $\mathrm{cm}$ level. The magnitude of displacements observed at each point also show a temporal variation according to the eruption characteristics. The results show that deformation during eruption tends to be local, e.g. just around the crater. Pressure source is difficult to be properly modeled from GPS results, due to limited GPS data available and differences in topography, geological structure and/or rheology related to each GPS station.
\end{abstract}

Keywords: Papandayan; Eruption; GPS Survey; Deformation.

\section{$1 \quad$ Introduction}

Papandayan volcano lies at the southern part of Garut Regency and is about 70 $\mathrm{km}$ southeast of Bandung. Its peak reaches up to around $2665 \mathrm{~m}$ above sea level or $1950 \mathrm{~m}$ above the Garut plateau. There are also other volcanoes and faults around Papandayan as shown in Figure 1.

Based on the historical records, Papandayan volcano is one of the active volcanoes in Indonesia. Its earliest recorded eruption, and most violent and 
devastating outburst occurred in 1772 whereas the summit portion was thrown out and covered an area of about 250 square $\mathrm{km}$. The other eruptions occurred on $1882,1923,1924,1925,1926,1927,1942,1993$, and the most recent was on (November to December 2002) period.

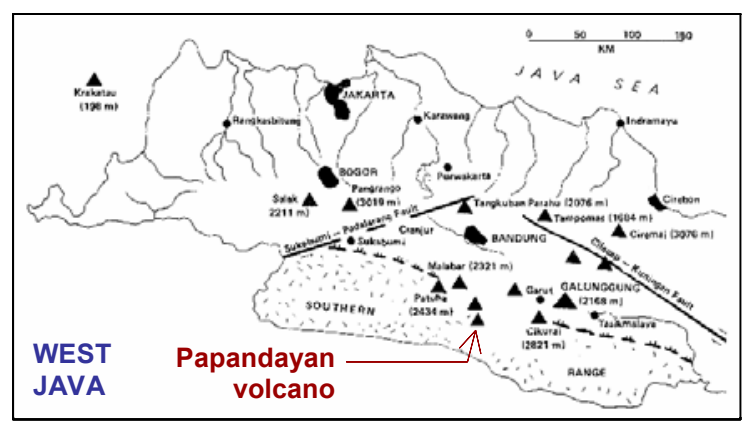

Figure 1 Location of Papandayan volcano.

Papandayan volcano, as shown in Figure 2, is a large composite volcano, constructed of alternating layers of lava and ash, and other fragmental volcanic rock debris formed by explosive eruptions over the past several hundreds years [DVGHM, 2003]. A large horseshoe-shape crater extended to the northeast producing avalanche deposit consisted of intermixed volcanic debris and alternated rocks, with steep-sided crater walls. Numerous small vents are within the crater and many others with solfataras emitting smoke and hot fumes from its inner sides.

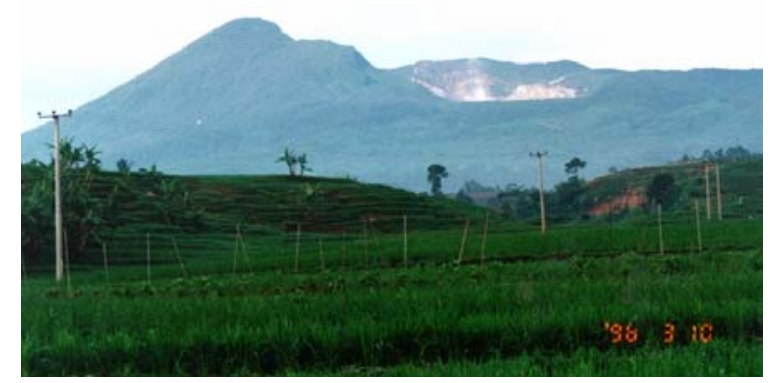

Figure 2 Papandayan volcano.

According to DVGHM (2003), the geological structures found at Papandayan volcano were craters and faulting. Faulting indications found as brecciation, topography lineament and destruction zone, interpreted as normal and strike-slip faults with northeast-southwest and northwest-southeast direction. Faulting structure can be found at summit area and some others found at northwest and 
southeast slope of Papandayan. Craters appeared at the summit area consist of six main craters known as Brungbrung, Tegal Alun-alun, Nangklak, Mas, Manuk and Baru crater.

Papandayan volcano activity is continuously monitored from the observatory, located in Pangauban Village about $10 \mathrm{~km}$ in the northeast direction from the crater. The observatory is equipped by one seismograph telemetric system (Kinemetrics PS-2 type), while a seismometer has already been installed at upper part of Kawah Mas. Measurement of the temperature of solfataras and chemical analysis of the volcanic gases at Papandayan craters are also carried out as part of monitoring. The deformation of the volcano has been also studied using Leveling, EDM, and GPS surveys.

\section{$2 \quad$ Papandayan Eruption 2002}

The most recent eruptions of Papandayan volcano occurred in the period of November to December 2002. Several small and large eruptions occurred during this two month period.

The first eruption occurred on November $11^{\text {th }}$, while the largest one was on November $15^{\text {th }}$ and the second largest was on November $20^{\text {th }}$. The Papandayan activity tends to decrease afterward and the latest significant eruption occurred on December 18th. Following is a truncated report given by DVGHM (2002) on the chronology of Papandayan eruption activity.

Early October 2002, seismograph started to record a deep volcanic earthquake (volcanic-a type). Mid of October 2002, a shallow volcanic earthquake (volcanic-b type) was recorded, which means that there was an earthquake migration toward surface. The existence of this volcanic earthquake continued till eruption and landslide closer.

On 11 November 2002, at 04.52 and 04.54 local time there were feltshocks with II MMI scale. This earthquake triggered Papandayan instability and caused tremor at 12.00 local time. This tremor continue till 15.06 with amplitude of 6 $\mathrm{mm}$. At 15.30 local time, freatic eruption occurred from Kawah Baru (formed in 1942). Instability condition as a result of previous feltshocks and this freatic eruption caused landslide (at 16.50 local time) at the west wall of old crater complex. This material of landslide was taken along the river and formed lahar flood.

Until 14 November 2002, eruption progressed into freatomagmatic type. There are seven eruption points inside Kawah Baru, which four of them acted as sources of sporadic magmatic eruption, while the other three points acted as 
continuous ash eruption sources. On November $14^{\text {th }}$, between 00.17 and 11.50 local time, magmatic eruptions occurred 17 times. Ash eruptions appeared as thick-grey color and reached an altitude of 500-1000 m above the crater.

On Friday, 15 November 2002, at 06.30 local time, a large eruption occurred with big rumble (see Figure 3). This eruption spewed out ash which reached a 5 $\mathrm{km}$ altitude above the summit with radius of about $20 \mathrm{~km}$. The frequency of the eruption increased from 17 times on Thursday (November 14th) to almost every minute. The observer at Papandayan observatory recorded that between 6.33 and $07.45 \mathrm{am}, 13$ times of eruptions had occurred. Between 07.45 and 11.07 am, 30 eruptions had occurred. Papandayan volcano activity level was increased to level 4 (warning level). The villagers around volcano had been evacuated, and the number of evacuee was about 6000 people.

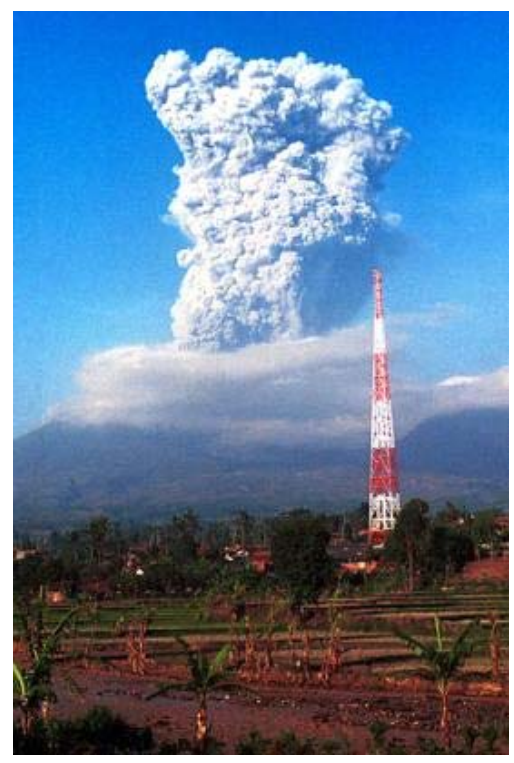

Figure 3 Papandayan eruption on 15 Nov. 2002.

Visual observation on November $16^{\text {th }}(06.00-18.00$ local time) noted a whitethick ash plume which rose westward to an altitude of about $300 \mathrm{~m}$, weak medium pressure and no rainfall around the volcano. Seismograph recorded events of continuous explosion, continuous emission, six volcanic, one tectonic and continuous tremors. Volcano status was still in level 4.

On 17 and 18 November 2002 volcanic activity was dominated by ash emission, while medium pressured ash explosion occurred continuously. Visual observation noted a white-thin ash plume rose westward from the crater to an 
altitude of about 200-700 m, with medium pressure, and no rainfall around the volcano. Seismic activity noted continuous emission earthquake, continuous explosion, two volcanic earthquakes, continuous tremors and tectonic earthquakes. Since 18 November 2002, 12.00 local time, volcano status is reduced into level 3.

On Wednesday November $20^{\text {nd }}$ the activity of Papandayan had increased again compared with activities on two previous days. At 5.02 am local time, eruption occurred for 25 minutes and spewed out billow of smoke which was about 1500 meters height. Ash emission spreads in radius about $2 \mathrm{~km}$ to northwest of the crater. At $8.00 \mathrm{am}$, eruption occurred again in which ashfall occurred and drifted westward in radius of about $20 \mathrm{~km}$ from the crater. At 9.05 am the ash eruption occurred and produced a dark-grey ash reaching an altitude of 2000 $3000 \mathrm{~m}$ above the summit. This eruption resulted in the area around Terminal I (one), which is located $2 \mathrm{~km}$ east from Papandayan crater, was covered by 2 $\mathrm{mm}$ thick of dark-grey ash. According to DVGHM, this eruption has a source in Nangklak crater, one of the eruption points of Papandayan. Seismic activity was revealed as volcanic, tremor and medium intensity of continuous emission. On this day seismic record showed the occurrences of one explosion earthquake and 17 shallow volcanic, one deep volcanic, two tectonic, one low frequency earthquakes and continuous tremors.

After the November $20^{\text {nd }}$ eruption, there were still smaller eruptions occurred, namely on 26 November and 9, 12 and 18 December, as shown in Figure 4.

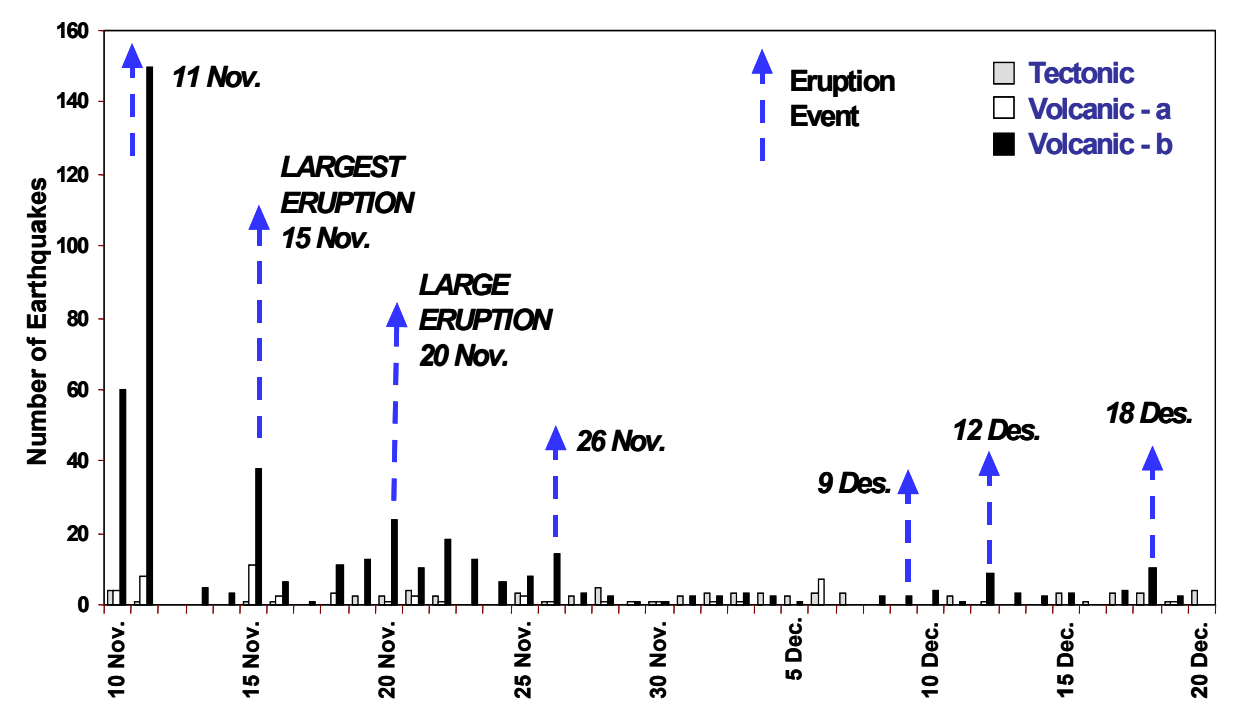

Figure 4 Seismicity and eruption events of Papandayan volcano in the period of 10 November to 20 December 2002. 


\section{GPS Surveys in Papandayan}

GPS surveys for monitoring the deformation of Papandayan volcano was firstly started in October 1998. Until June 2003, as shown in Table 1, there have been seven GPS campaigns conducted, where one of them was conducted during the eruption of Papandayan in November 2002. The surveys were carried out by the Department of Geodetic Engineering, Institute of Technology Bandung in cooperation with the Directorate of Volcanology and Geological Hazard Mitigation, Ministy of Energy and Mineral Resources.

Configuration of GPS stations being used for Papandayan volcano deformation monitoring is shown in Figure 5. As already shown in Table 1, not all stations were observed at each campaign. Some stations were added later to the network. Stations NGLK, KMAS and DPN0 were destroyed by the 2002 eruption and therefore can not be used afterward. A new station, i.e. KWAH2 was observed since the $7^{\text {th }}$ survey, and it was located near the previous DPN0 station.

\begin{tabular}{|c|c|c|}
\hline Survey & Period & GPS Stations \\
\hline 1 & 22-23 Oct. 1998 & POS, NGLK, KAWH, PARK, BMNG \\
\hline 2 & 25-26 March 1999 & POS, NGLK, KAWH, PARK, BMNG \\
\hline 3 & 23-24 Dec. 1999 & POS, NGLK, KAWH, PARK, BMNG \\
\hline 4 & 23-24 June 2001 & POS, NGLK, KAWH, PARK, BMNG \\
\hline \multirow{2}{*}{5} & 11-12 Aug. 2002 & $\begin{array}{c}\text { POS, NGLK, KAWH, PARK, BMNG, } \\
\text { DPN0, DPN03, DPN05, KMAS }\end{array}$ \\
\hline \multirow{3}{*}{6} & 13-15 Nov. 2002 & POS, PARK, DPN0, DPN03, DPN05 \\
\cline { 2 - 3 } & 17 Nov. 2002 & POS, PARK, DPN0 \\
\cline { 2 - 3 } & 18 Nov. 2002 & POS,DPN0, KMAS, KWAH \\
\cline { 2 - 3 } & 19 Nov. 2002 & POS, BKMG \\
\hline \multirow{2}{*}{7} & 9-10 June 2003 & $\begin{array}{c}\text { POS, KAWH, PARK, BMNG, DPN03, } \\
\text { DPN05, KWAH2 }\end{array}$ \\
\hline
\end{tabular}

Table 1 Periods of GPS surveys in Papandayan.

The first four surveys are carried out using 5 (five) GPS dual-frequency geodetic type receivers, e.g. Topcon Z-XII3 and Leica System 300, and since the $5^{\text {th }}$ survey two more Leica System 500 receivers were also being used. At each campaign station POS observed the satellites for the whole period, while the observation session at other points ranges from 8 to 16 hours.

GPS data processing is done using BERNESSE 4.2 scientific software [Beutler et al., 2001]. Processing is done in radial mode from POS station. POS station is assumed to be stable for the deformation study, and its coordinates are computed from an Indonesia IGS station in Bakosurtanal, Cibinong, Bogor. For all computations, precise ephemeris is used, residual tropospheric and residual 
ionospheric biases are estimated. All cycle ambiguities are successfully resolved and final position solution is obtained using narrow-lane signal [HofmannWellenhof et al., 1994].

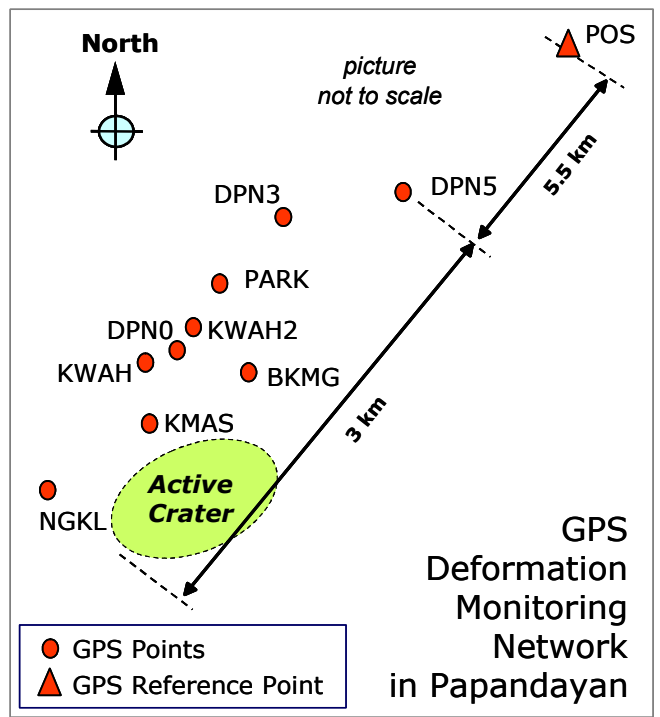

Figure 5 Configuration of GPS Network in the Papandayan volcano area.

Standard deviations of the station coordinates obtained in seven GPS campaigns that have been conducted in Papandayan volcano are shown in Figure 6. In general it can be seen that the obtained precision level of coordinates is in the level of several $\mathrm{mm}$. The horizontal components (easting and northing) have standard deviation better than $4 \mathrm{~mm}$, and in general they are about 1 to $2 \mathrm{~mm}$ level. The ellipsoidal height components have standard deviations better than 7 $\mathrm{mm}$, and in general are about 2 to $5 \mathrm{~mm}$ level.

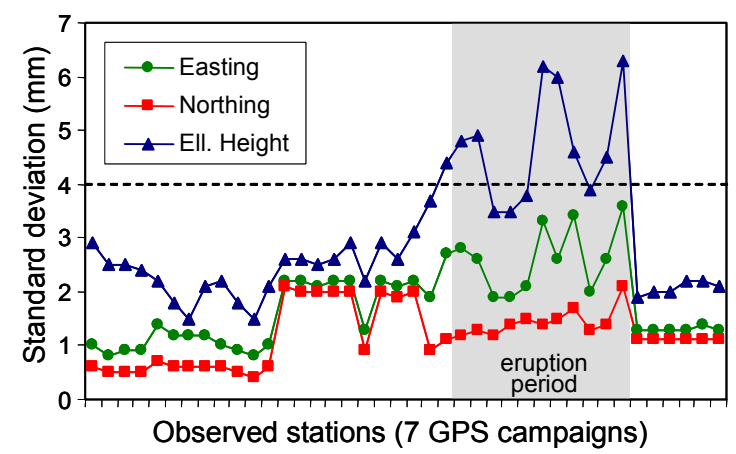

Figure 6 Standard deviations of the estimated coordinates of GPS stations from 7 surveys. 
Please also note in this Figure that the standard deviations obtained during the eruption period ( $6^{\text {th }}$ survey) have slightly worse precision in easting and ellipsoidal height components. The reason for this is still uncertain and needs further research.

\section{Results of GPS Surveys during Normal Period of Papandayan}

In order to see the deformation characteristic of Papandayan during the normal period, the results from first five GPS surveys were used. The computed changes in GPS derived horizontal distances between points are shown in Figure 7. The distances are computed using the coordinates obtained from Bernesse 4.2 processing results, and their truncated values are shown in Table 2.
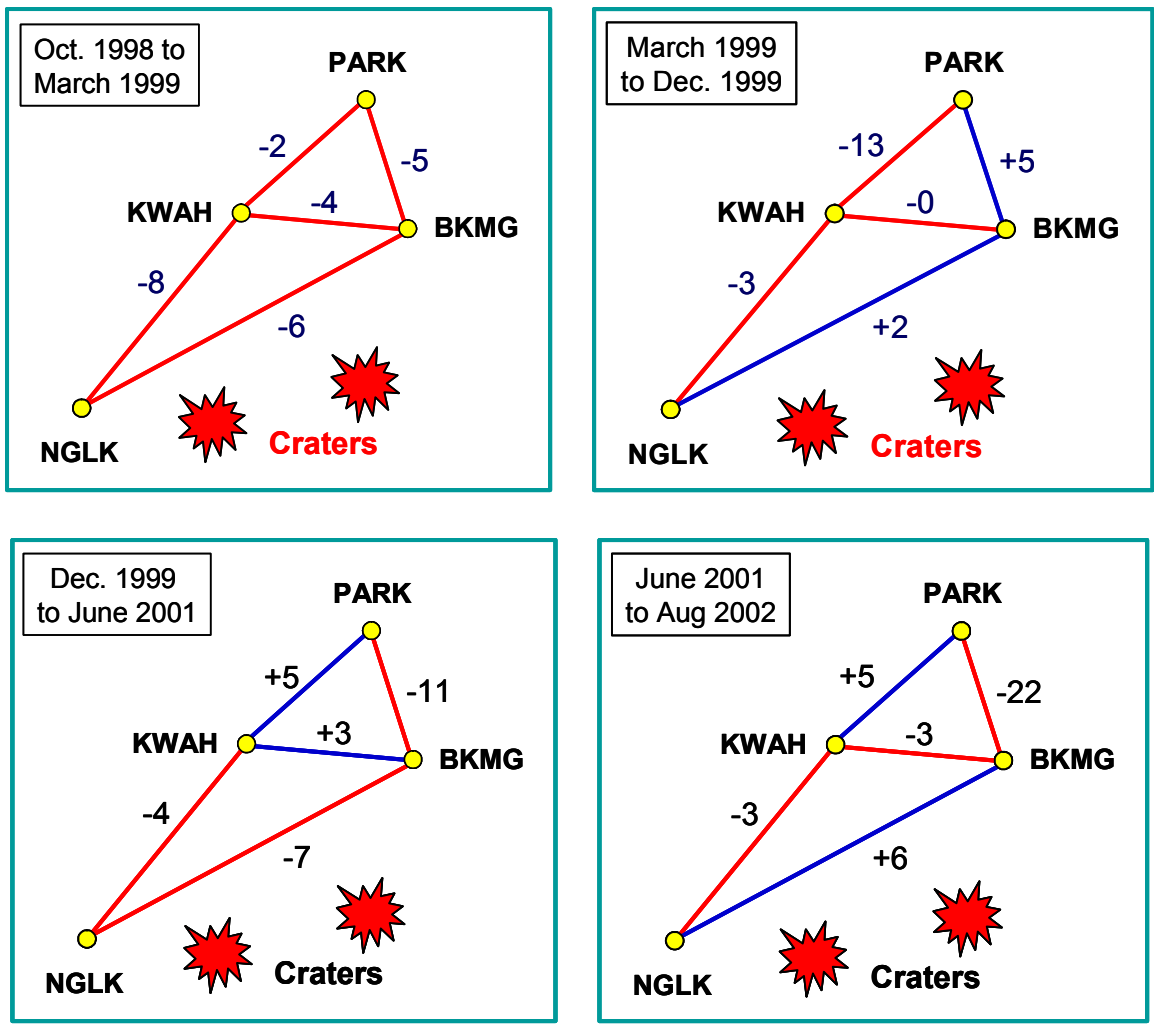

Figure 7 GPS Horisontal Distance Changes (in mm) During Normal Periods of Papandayan.

From this Figure it can be seen that during normal periods of Papandayan activity, the GPS observed horizontal distance changes were just in order of 
several $\mathrm{mm}$ level, with a maximum of $1-2 \mathrm{~cm}$ level. Considering the baseline lengths of less than 1 to $2 \mathrm{~km}$ (see Table 2), then in term of changes in ppm (part-per-million), the distance changes during a normal period of Papandayan are just in the order of several ppm level, with a maximum of about 20 to 40 ppm for a few baselines.

\begin{tabular}{|c|c|c|c|}
\hline Station & PARK & KWAH & BKMG \\
\hline KWAH & 705.1 & - & 731.0 \\
\hline BKMG & 574.6 & 731.0 & - \\
\hline NGLK & 1753.4 & 1050.8 & 1598.3 \\
\hline
\end{tabular}

Table 2 Horizontal distances between GPS stations in $\mathrm{m}$.

It should be noted also in Figure 7 that in the last normal period before the 2002 eruption, i.e. June 2001 to August 2002, there was a sign of extension across the crater (NGLK-BKMG baseline) and a relatively significant shortening of (BKMG-PARK) baseline in the amount of about $40 \mathrm{ppm}$. It is difficult to verify at this moment whether this significant shortening of baseline was caused by the increase of Papandayan activity prior to the Nov. 2002 eruption period.

\section{Results of GPS Surveys Prior to Largest Eruption of Papandayan}

The eruption of Papandayan started on November $11^{\text {th }} 2002$ with relatively a small explosion, and the largest eruption occurred on November $15^{\text {th }}$.

After the first eruption occurred, GPS survey was immediately called to be conducted. Due to the unsafe situation around the volcano crater and availability of only two GPS receivers at that emergency time, only certain points could be observed.

\begin{tabular}{|c|l|r|r|r|}
\hline Station & \multicolumn{1}{|c|}{ Date } & \multicolumn{1}{c|}{$\mathrm{dE}(\mathrm{cm})$} & $\mathrm{dN}(\mathrm{cm})$ & $\mathrm{dh}(\mathrm{cm})$ \\
\hline DPN0 & 13 Nov. & +10.6 & +9.2 & +28.7 \\
\hline DPN3 & 14Nov. & -5.5 & -1.4 & +9.6 \\
\hline
\end{tabular}

Table 3 Changes in the coordinate components since August 2002 (the $5^{\text {th }}$ GPS survey).

Prior to November $15^{\text {th }}$ eruption two GPS sessions were conducted, namely on November $13^{\text {th }}$ POS and DPN0 stations were observed and on November $14^{\text {th }}$ POS and DPN3 were observed. The coordinates of DPN0 and DPN3 estimated from GPS data on those observed days are then compared to their coordinates estimated by the $5^{\text {th }}$ GPS survey conducted on August 2002. Their coordinate differences are given in Table 3. 
The results show that prior to the largest November $15^{\text {th }}$ eruption, significant inflation in the order of a few dm occurred around the crater area. Station DPN0 which is located about 500 meter from the erupting crater shows an inflation of about $3 \mathrm{dm}$, while station DPN3 which is about $1.6 \mathrm{~km}$ from the crater show about $1 \mathrm{dm}$ inflation, in this period of about three months.

Due to limited data, it is difficult to determine when this inflation process was really started. However considering that in the mid of October shallow volcanic earthquakes were started to be recorded at Papandayan [DVGHM, 2002], it can be expected that the inflation process started at that time. This implies the inflation rate of about $3 \mathrm{dm} /$ month for area close to the crater, and the rate of about $1 \mathrm{dm} /$ month for the area located about $1.5 \mathrm{~km}$ from the crater.

It should be mentioned here that a relatively large deformation in the order of a few to several $\mathrm{dm}$ before the volcano eruption was also observed at other volcanoes such as Etna [Bonaccorso, 1999], Merapi [Young et al., 2000], Kozushima [JMA, 2000], Okmok, Alaska [Mann \& Freymueller, 2002], Miyakejima [Meilano et al., 2003]. A very large deformation in the order of several ten of meters had even observed before the eruption of Usu volcano [Jousset et al., 2003].

\section{Results of GPS Surveys during Eruption Period of Papandayan}

After the largest eruption of November $15^{\text {th }}$ and before the second largest eruption on November $20^{\text {th }}$, GPS observations were conducted at several GPS stations, namely at POS, PARK and DPN0 on November 17th, at POS, DPN0, KMAS and KWAH on November $18^{\text {th }}$, and at POS and BKMG on November $19^{\text {th }}$.

In order to see the temporal variation of coordinate components during this eruption period, GPS data were processed in differential kinematic mode using Bernesse 4.2. The kinematic solution was done with $30 \mathrm{sec}$ data interval, and POS was used as the reference station. The obtained temporal variations of the height components are shown in Figure 8.

In this Figure 8 it can be realized that the estimated vertical scatters of GPS stations could reach the order of up to $1-2 \mathrm{dm}$ at the points closest to the craters, e.g. DPN0 and KMAS. It is interesting to note however, that the characteristics of vertical motion are not the same for each station.

DPN0 station showed a deflation on November $17^{\text {th }}$ which may indicate the resting of volcano after the November $15^{\text {th }}$ eruption. On November $18^{\text {th }}$, 
however, DPN0 station again showed an inflation at the end of day, which may indicate the regaining power period of Papandayan before the November $20^{\text {th }}$ eruption. KMAS station, the even closer point to the crater had shown an earlier sign of inflation in the morning of November $18^{\text {th }}$.
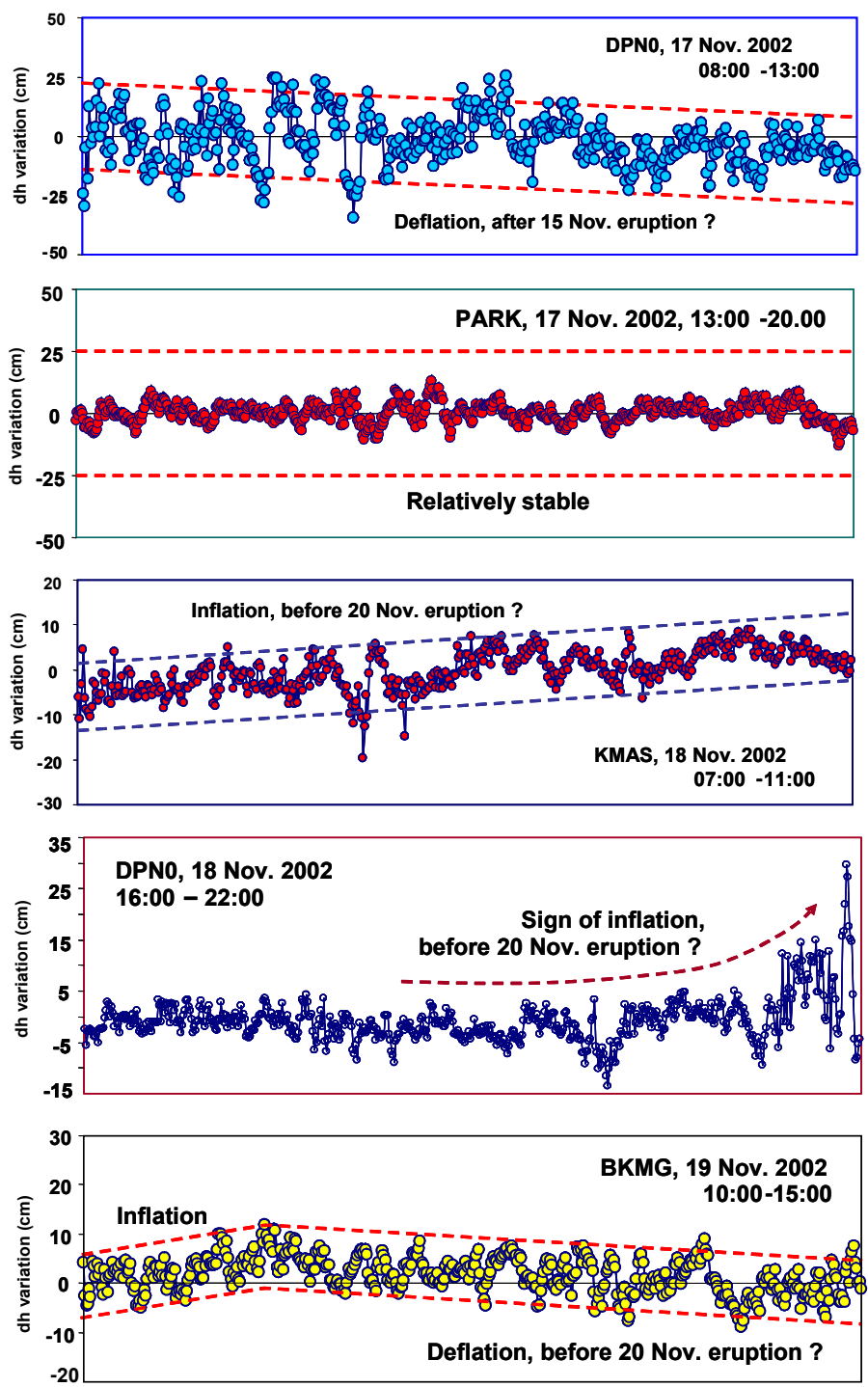

Figure 8 Temporal Height Variation of GPS Station (2002 Eruption Period, 1719 November).

Inflation and deflation of BKMG station as shown in Figure 8 can be explained if the deeper and shallower pressure sources are considered [Kimata, 2003]. On November $19^{\text {th }}$ at first a pressure in the deeper source increase and caused the 
inflation of BKMG station. After that the pressure went up to the shallower source, and the deeper source became the deflation source for BKMG station. At this time the shallower source became the inflation source for area around the crater and then triggered the November $20^{\text {th }}$ eruption. This hypothesis unfortunately could not be validate with other station results, since only POS and BKMG stations were observed on November $19^{\text {th }}$.
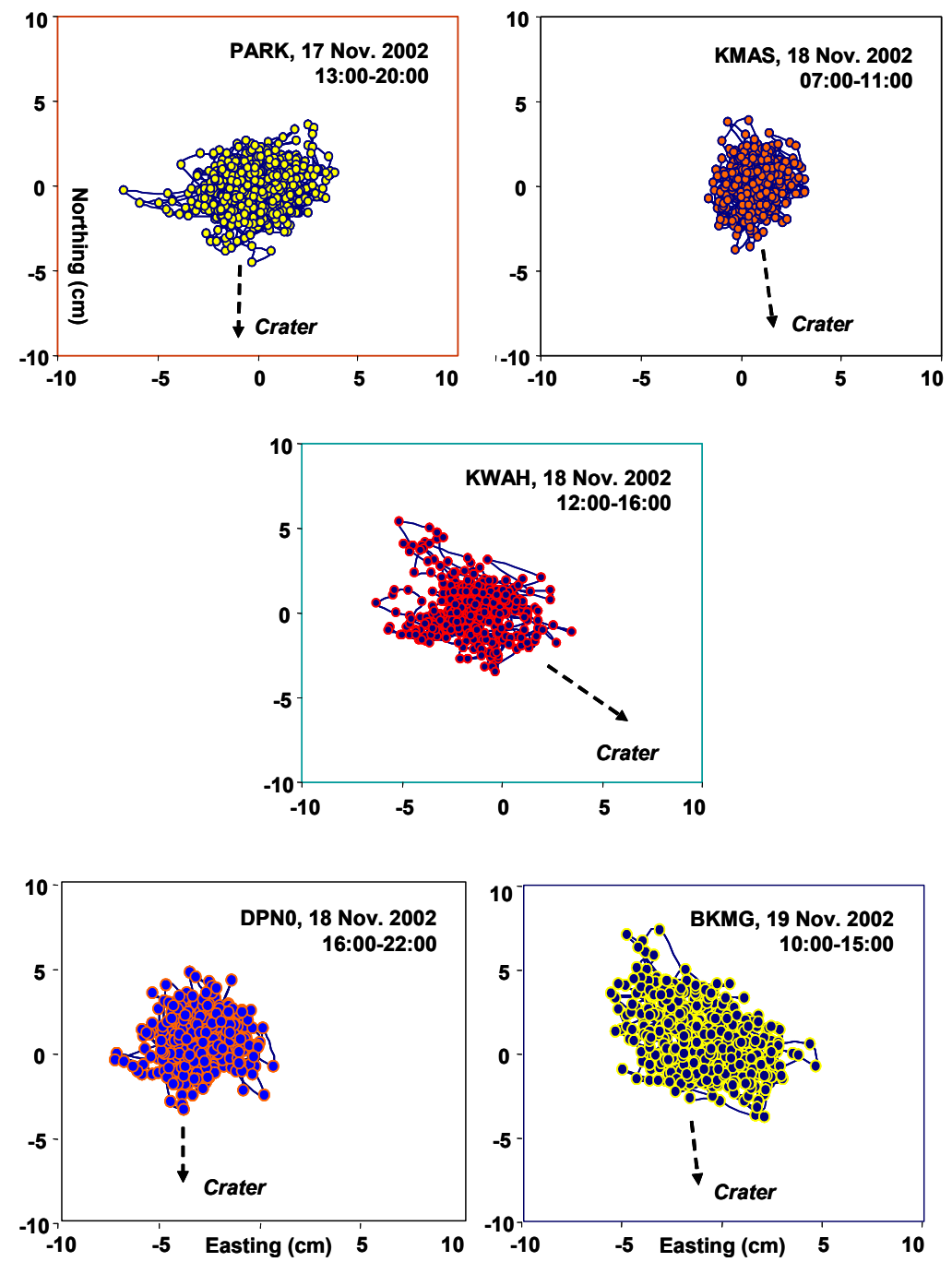

Figure 9 Horizontal Motion of GPS Stations (2002 Eruption Period, 17-19 November).

The results on Figure 8 also indicate that the final effects of Papandayan activity on the vertical deformation were also governed by the topography, geological structure and rheology of the area. In this case spatial and temporal variations of 
the effects are apparent. A more detail discussion on the effects of topography and rheology on ground deformation in volcanic region can be seen in [Trasatti et al., 2003]. The temporal height variation results shown in Figure 4 also suggested that the availability of GPS continuous monitoring system can be very useful in anticipating the coming of large eruption event.

The horizontal point motion of the GPS stations from the same kinematic solution are shown in the following Figure 9. All stations showed the horizontal scatters in the order of several $\mathrm{cm}$. It is interesting to note that KMAS station which is the closest station to the erupting crater (i.e. about $100 \mathrm{~m}$ ) has a relatively smaller horizontal scatter. Please also notice the existence of quite elongated scatters of PARK, KWAH and BKMG horizontal point motions.

Further research has to be done in order to provide a better physical explanation on the above temporal variations in the vertical and horizontal components of GPS stations. Actually it will be interesting in this case to correlate the GPSderived point motion with the seismicity of the corresponding point at the same time period. During Papandayan eruption, however only two seismic stations were operated around the crater area, namely around KWAH and PARK stations of GPS. Moreover with a $30 \mathrm{sec}$ GPS data rate being used, a detail and meaningful correlation cannot be done properly.

\section{$7 \quad$ Results of GPS Surveys after Eruption Period of Papandayan}

On 9 and 10 of June 2003 the latest GPS survey was conducted in Papandayan volcano area. Seven stations were observed, namely POS, KAWH, PARK, BMNG, DPN03, DPN05 and KWAH2. Stations NGLK, KMAS and DPN0 were destroyed by the November $20^{\text {th }}$ eruption and therefore could not be observed any longer. KWAH2 station is the new station located around the previous DPN0 station.

In order to see the effects of the 2002 eruption on the ground deformation, the station coordinates obtained by the June 2003 GPS survey are compared with the corresponding coordinates obtained by the August 2002 GPS survey. The comparison results are shown in terms of horizontal distance and height changes as depicted in Figures 10 and 11.

The results shown in these Figures suggest that the 2002 Papandayan eruption had introduced the inflation of area around the crater in the order of 1 to $2 \mathrm{dm}$. The area closer to the crater experienced the largest displacement and uplift.

Results on Figure 11 also show that the eruption also caused the deflation on PARK and DPN3 stations, which are located about 1 and $1.6 \mathrm{~km}$ from the 
craters. These inflation and deflation phenomena can be caused by the existence of both a shallow inflation source and a deep deflation source [Kimata, 2003]. However, more data are still required to explain these inflation and deflation phenomena.

The fact that the changes were observed on June 2003, which is about 6 months after the eruption period, shows the viscoelastic nature of the area around Papandayan crater.

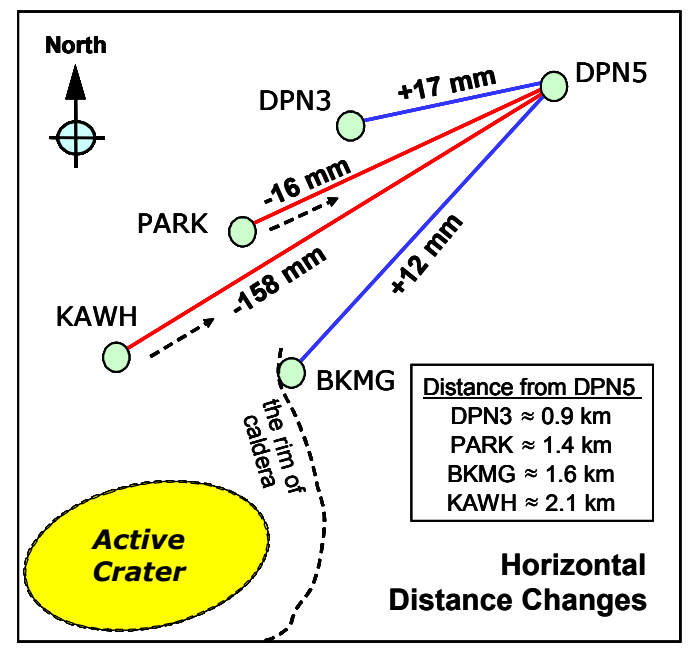

Figure 10 GPS derived Horizontal Distance Changes from August 2002 to June 2003.

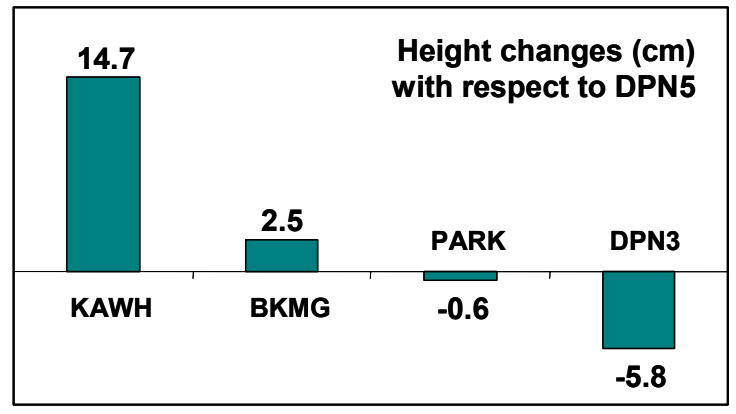

Figure 11 GPS derived Height Changes from August 2002 to June 2003.

\section{$8 \quad$ Closing Remarks}

GPS surveys had detected a ground deformation in the level of several $\mathrm{cm}$ to a few dm level during the eruption of Papandayan volcano in November 2002. 
The obatained deformation tends to be local, e.g. just around the crater within about one km range.

Pressure source modeling of volcano deformation actually can be based on several models [Mogi, 1958; Okada, 1985; Trasatti, 2003]. Considering the relatively limited GPS data available and differences in topography, geological structure and/or rheology related to each GPS station, no pressure source modeling is attempted at the present time. This will be done when more data are available; not just from GPS surveys, but also from EDM and Leveling surveys. Moreover data related to topography, geological structures and rheology of Papandayan volcano should be taken into consideration.

In order to better contribute to the pressure source modeling, GPS network in Papandayan should also be extended to cover all sides of Papandayan volcano. More collocated points with EDM and leveling points will also be tempted.

The 2002 eruption of Papandayan also suggested that the availability of GPS continuous monitoring system can be very useful in anticipating the coming of large eruption event of a volcano. The University of New South Wales (UNSW) Australia had actually installed such a system on Papandayan volcano [Janssen et al., 2002]. The operation of the system however had been terminated long before the November 2002 eruption.

\section{References}

1. Beutler, G., H. Bock, E. Brockmann, R. Dach, P. Fridez, W. Gurtner, U. Hugentobler, D. Ineichen, J. Johnson, M. Meindl, L. Mervant, M. Rothacher, S. Schaer, T. Springer, R. Weber (2001). Bernese GPS software version 4.2. U. Hugentobler, S. Schaer, P. Fridez (Eds.), Astronomical Institute, University of Berne, $515 \mathrm{pp}$.

2. Bonaccorso, A. (1999). "The March 1981 Mount Etna eruption inferred through ground deformation modeling", Physics of the Earth and Planetary Interiors, Vol. 112, pp. 125-136.

3. DVGHM (2002). The website of the Directorate of Vulcanology and Geological Hazard Mitigation, Address: http://www.vsi.esdm.go.id/.

4. Hofmann-Wellenhof, B., H. Lichtenegger, and J. Collins (1994). Global Positioning System, Theory and Practice. Third, Revised Edition, Springer Verlag, Wien.

5. Janssen, V., C. Roberts, C. Rizos and H.Z. Abidin (2002): Low-Cost GPS-Based Volcano De-formation Monitoring at Mt. Papandayan, Indonesia, Journal of Volcanology and Geothermal Research, 115(1-2), 139-151. 
6. JMA (Japan Meteorological Agency) (2000). "Recent seismic activity in the Miyakejima and Niijima-Kozushima region, Japan, the largest earthquake swarm ever recorded", Earth Planets Space, 52(8), i-viii, 2000.

7. Jousset, P., H. Mori and H. Okada (2003). "Elastic models for the magma intrusion associated with the 2000 eruption of Usu Volcano, Hokkaido, Japan", Journal of Volcanology and Geothermal Research, Vol. 125, Issues 1-2, 10 July, pp. 81-106.

8. Kimata, F. (2003). Personal Communication. Research Center for Seismology and Volcanology (RCSV), Nagoya University, Nagoya, 19 July.

9. Mann, D. and J. Freymueller (2002). "Deformation associated with the 1997 eruption of Okmok volcano, Alaska", Journal of Geophysical Research, Vo. 107, No. B4, 10.1029/2001JB000163.

10. Meilano I., F. Kimata, N. Fujii, S. Nakao, H. Watanabe, S. Sakai, M. Ukawa, E. Fujita, and K. Kawai (2003). "Rapid Ground Deformation of Miyakejima Volcano on June 26-27, 2000 Detected by Kinematic GPS Analysis" Earth Planets Space. In press.

11. Mogi, K. (1958). "Relations between the eruptions of various volcanoes and the deformation of the ground surfaces around them". Bulletin of Earthquake Research Institute Uniiversity of Tokyo, Vol. 36, pp. 99-134.

12. Okada, Y. (1985). "Surface deformation due to shear and tensile faults in a half-space". Bulletin Seismological Society of America, Vol. 75, pp. 1135-1154.

13. Trasatti, E., C. Giunchi, M. Bonafede (2003). "Effects of topography and rheological layering on ground deformation in volcanic regions", Journal of Volcanology and Geothermal Research, Vol. 122, pp. 89-110.

14. Young, K.D., B. Voightc, Subandriyob, Sajiman, Miswanto and T. J. Casadevall (2000), "Ground deformation at Merapi Volcano, Java, Indonesia: distance changes, June 1988-October 1995", Journal of Volcanology and Geothermal Research, Vol. 100, No. 1-4, July, pp. 233259. 